\title{
Characterization of novel microsatellite loci for Myzomela cardinalis and $M$. rubrata honeyeaters, and cross-amplification in other species
}

\author{
Henri A. Thomassen • Kenneth C. Jones • \\ John P. Pollinger • Thomas B. Smith
}

Received: 19 October 2009/ Accepted: 20 October 2009/Published online: 5 November 2009

(C) The Author(s) 2009. This article is published with open access at Springerlink.com

\begin{abstract}
Myzomela honeyeaters are distributed from eastern Austalia and Indonesia throughout the islands of the tropical Pacific, a biodiversity hotspot that is particularly vulnerable due to small population sizes, habitat destruction, and high levels of isolation between islands. We developed fourteen microsatellite loci for Myzomela honeyeaters from the tropical Pacific. Microsatellites were tested for polymorphism on a panel of 104 individuals. The number of alleles ranged from 3 to 23 , observed heterozygosity from 0.067 to 0.913 , and the fixation index from -0.143 to 0.634 . Cross-amplification was tested in 18 different species and subspecies in the genus Myzomela from throughout the Pacific, Australia, and eastern Indonesian archipelago. These new microsatellites could potentially be useful in making informed conservation decisions regarding Myzomela honeyeaters on the islands of the tropical Pacific.
\end{abstract}

Keywords Microsatellite - Honeyeater - Pacific . Meliphagidae $\cdot$ Myzomela

H. A. Thomassen $(\bowtie) \cdot$ J. P. Pollinger · T. B. Smith Center for Tropical Research, University of California, La Kretz Hall, Suite 300, 619 Charles E. Young Dr. East, Los Angeles, CA 90095, USA

e-mail: hathomassen@ucla.edu

J. P. Pollinger · T. B. Smith

Department of Ecology and Evolutionary Biology,

University of California, 621 Charles E. Young Dr. East,

Los Angeles, CA 90095, USA

K. C. Jones

Genetic Identification Services Inc.,

9552 Topanga Canyon Blvd., Chatsworth, CA 91311, USA

\section{Introduction}

The tropical Pacific region constitutes one of the world's 25 designated hotspots of biodiversity (Myers et al. 2000), but at the same time its terrestrial avifauna is threatened in many ways. Population sizes are often small due to limited availability of suitable land surface, human land-use changes are continuing to decrease the original habitat (e.g., Buchanan et al. 2008), and introduced diseases (e.g., Jarvi et al. 2001), predators (e.g., Fritts and Rodda 1998), and non-native competing species greatly impact naïve bird populations (e.g., Steadman 2006). Contrary to traditional views that the islands of the tropical Pacific serve as a sink of biodiversity generated on the mainland, it was recently shown that diversification likely occurs in situ, and lineages that arise in the Pacific may recolonize the Australasian mainland (Filardi and Moyle 2005). Thus, the tropical Pacific constitutes a diverse and threatened region where biodiversity is likely being generated, yet it is relatively understudied.

One of the most widespread bird genera in the Pacific is constituted by the Myzomela honeyeaters (Pratt et al. 1987), a monophyletic group within the Meliphagidae (Driskell and Christidis 2004). The genus is distributed from the eastern Indonesian islands and Australia to the Pacific islands of the Commonwealth of the Northern Mariana Islands (CNMI) and American Samoa. Despite the fact that the Pacific species in this genus are still comparatively common, population trends are often negative. For example, a recent study reported a $72 \%$ decline of the Micronesian honeyeater (M. rubrata) population on Rota, CNMI (Amar et al. 2008). Whereas populations from many islands are often treated as a single species, it is plausible that the Myzomela honeyeaters of the Pacific constitute multiple recently diverged taxa, and should be treated as such for conservation purposes. 
Here we describe the isolation and characterization of 15 novel tri- and tetranucleotide microsatellite loci from $M$. cardinalis and $M$. (cardinalis) rubrata populations on six islands ( $n=104)$ in the northern tropical Pacific: Sarigan, Saipan, Rota (CNMI), Yap, Chuuk, and Pohnpei (Federated States of Micronesia). Blood samples (50-100 $\mu \mathrm{l})$ were taken from captured birds and stored in lysis buffer. No blood samples were available from the population on Sarigan, in which case we used feather samples for DNA extractions. DNA was extracted using the Qiagen QIAamp DNA Mini Kit using the manufacturer's protocol for either blood or tissue. DNA extractions from blood samples were used to create an enriched library at Genetic Identification Services, Inc. (Chatsworth, California). Details on the enrichment procedure can be found in Jones et al. (2000). In brief, the extracted DNA was incompletely digested using blunt-end restriction enzymes BsrB1, EcoRV, HaeII, PvuII, RsaI, ScaI, and StuI. HindIII adaptors were attached to fragments of 300-750 bp long. Fragments containing target repeat motifs were captured using $5^{\prime}$-biotinylated probes. Capture molecules with the following repeat motifs were used: AAC, ATG, CATC, and TAGA. Captured fragments were subsequently amplified using a primer complementary to the adaptor, digested with HindIII and ligated into the HindIII site of pUC19. Plasmids were electroporated into E. coli $\mathrm{DH} 5 \alpha$, and recombinant clones were selected for sequencing on an ABI 377 sequencer using ABI Prism Taq dye terminator cycle sequencing methodology.

Primers were originally designed for 28 loci using WebSat (Martins et al. 2009). Of these, 15 loci amplified

Table 1 Microsatellite loci developed for Myzomela honeyeaters

\begin{tabular}{|c|c|c|c|c|c|c|c|}
\hline Locus/genbank acc. no. & Repeat motif & Primer sequence $\left(5^{\prime}-3^{\prime}\right)$ & $N_{\mathrm{a}}$ & Size range & $H_{\mathrm{O}}$ & $H_{\mathrm{E}}$ & $F_{\text {is }}$ \\
\hline Mr 11 & GTT & GTTTGTTTGTTTGTTTGGGG & 8 & $146-167$ & 0.291 & 0.797 & 0.634 \\
\hline GU135610 & & TGCTAAAAGGGGAAGAGACTTA & & & & & \\
\hline Mr 12 & CAA & ATATTACAGGAGGCGGGGT & 3 & $153-159$ & 0.067 & 0.065 & -0.030 \\
\hline GU135611 & & TCСАСТСТТТАТТССААССАТС & & & & & \\
\hline Mr 15 & GAT & AAACTGAGGTGGGAGCTTG & 12 & $107-140$ & 0.702 & 0.877 & 0.199 \\
\hline GU135612 & & AGGGGTTTGTGCCTCCAT & & & & & \\
\hline Mr 16 & ATG & CAGGTTGAGGTAAGAACAGCTT & 11 & $161-200$ & 0.846 & 0.838 & -0.010 \\
\hline GU135613 & & GTCCAGTAGGTGATGAGCAAAT & & & & & \\
\hline Mr 27 & ATCC & AAACCACTGACAAAATGCCTC & 10 & $167-203$ & 0.740 & 0.799 & 0.073 \\
\hline GU135614 & & ACTGAGAGATGGATGGATCAAG & & & & & \\
\hline $\mathrm{Mr} 28 \mathrm{~A} / \mathrm{B}$ & TCCA & CAACCAACCAACCATCAAAT & 15 & $107-227$ & 0.827 & 0.903 & 0.084 \\
\hline GU135615 & & TATATGGGCATGACTGCGTA & & $240-284$ & & & \\
\hline Mr 29 & GGAT & AGTTGTCAGAGACTTGGAATGG & 6 & $220-240$ & 0.712 & 0.742 & 0.040 \\
\hline GU135616 & & АТТАТСТССТССТССТССТСАС & & & & & \\
\hline Mr 34 & CCAT & СТТАСССААААССТССТССТС & 9 & $227-259$ & 0.904 & 0.791 & -0.143 \\
\hline GU135617 & & CACTTTCAGCGCAAATTACA & & & & & \\
\hline Mr 35 & CATC & TGACAGCAGGTGATGCAG & 13 & $143-191$ & 0.817 & 0.869 & 0.059 \\
\hline GU135618 & & TGTCTATACCTCTCTTTCCTCCT & & & & & \\
\hline Mr 36 & CATC & CATCGACCGTTATTTTCACTC & 7 & $155-179$ & 0.654 & 0.740 & 0.116 \\
\hline GU135619 & & CTCTTCTGGACTATGGCCTTG & & & & & \\
\hline $\operatorname{Mr} 40$ & (AGAT)ATAG(AGAT) & AGCTGCCCAAATAACTCACA & 14 & $165-233$ & 0.635 & 0.893 & 0.289 \\
\hline GU135620 & & TTCAGGGAATCTCCTGTCAC & & & & & \\
\hline $\operatorname{Mr} 41$ & (ATCT)A(ATCT) & TCTCCTGCTATCTCACATCTATCT & 12 & $137-205$ & 0.769 & 0.791 & 0.027 \\
\hline GU135621 & & TTGCCATCTTCTCTGTCTCAC & & & & & \\
\hline $\operatorname{Mr} 45$ & TCTA & GGTGCAGTCAAGATGTTTGTT & 16 & $119-183$ & 0.894 & 0.851 & -0.051 \\
\hline GU135622 & & TTTAAGAGCAGGAGAAGTCAGC & & & & & \\
\hline $\operatorname{Mr} 47$ & TATC & AGCACACCTAATGTCCTCCA & 23 & $133-229$ & 0.913 & 0.918 & 0.005 \\
\hline GU135623 & & GCGACATCACACATTTCAGA & & & & & \\
\hline $\operatorname{Mr} 48$ & AGAT & GTCCCAAGTGAATTTGCATAG & 16 & $151-211$ & 0.837 & 0.906 & 0.077 \\
\hline GU135624 & & TGTCTTTTCATGTTCCACCAC & & & & & \\
\hline
\end{tabular}

Shown are locus names, GenBank accession number, repeat motif, forward (top) and reverse (bottom) primers, number of alleles $\left(N_{\mathrm{a}}\right)$, fragment size ranges, observed $\left(H_{\mathrm{O}}\right)$ and expected heterozygosity $\left(H_{\mathrm{E}}\right)$, and fixation index $\left(F_{\text {is }}\right)$. Forward primers contained an additional 16-bp M13hybrid primer binding site on the $3^{\prime}$ end. Polymorphism was tested in 104 individuals, all of which amplified for the loci tested 
Table 2 Cross-amplification of developed microsatellite loci in members of the genus Myzomela

\begin{tabular}{|c|c|c|c|c|c|c|c|c|c|c|c|c|c|c|c|}
\hline Species & Mr11 & Mr12 & Mr15 & Mr16 & Mr27 & $\operatorname{Mr} 28$ & Mr29 & Mr34 & Mr35 & Mr36 & Mr40 & Mr41 & $\mathrm{Mr} 45$ & Mr47 & $\mathrm{Mr} 48$ \\
\hline M. albigula albigula & - & + & + & + & + & + & + & - & + & + & - & + & + & - & + \\
\hline M. blasii & - & + & + & + & - & - & + & - & + & + & - & + & + & - & + \\
\hline M. c. chermesina & + & + & + & + & + & + & + & - & + & + & - & - & + & + & + \\
\hline M. c. lifuensis & - & + & + & + & + & - & + & - & + & + & - & + & + & + & - \\
\hline M. c. sanfordi & + & + & + & + & + & - & - & - & + & + & - & + & + & + & + \\
\hline M. c. tenuis & + & + & + & + & + & - & - & - & + & + & - & + & + & + & - \\
\hline M. eques eques & - & + & + & + & + & + & - & - & + & + & - & + & + & - & + \\
\hline M. erythromelas & - & + & + & + & + & - & - & - & + & - & - & - & + & - & + \\
\hline M. jugularis & + & + & + & + & + & + & + & - & + & + & - & - & + & - & + \\
\hline M. lafargei & - & + & + & + & - & + & - & - & + & - & - & - & + & + & + \\
\hline M. malaitae & + & + & + & + & + & + & + & - & + & + & - & + & + & + & + \\
\hline M. melanocephala & - & + & + & + & + & + & + & - & + & + & - & + & + & + & + \\
\hline M. nigrita ernstmayeri & + & + & + & + & + & + & + & + & + & + & - & + & + & + & + \\
\hline M. obscura obscura & + & + & + & + & + & + & - & - & + & + & - & + & + & - & + \\
\hline M. rosenbergii rosenbergii & - & + & + & + & + & + & - & - & + & + & - & + & + & - & + \\
\hline M. sclateri & - & + & + & + & + & + & + & - & + & + & - & + & + & + & + \\
\hline M. sanguinolenta sanguinolenta & + & + & + & + & + & + & + & - & + & + & - & + & + & + & + \\
\hline M. tristrami & - & + & + & + & + & + & + & - & + & + & - & - & + & + & + \\
\hline
\end{tabular}

Because only a single toe pad sample for each taxon was available and tested, the level of polymorphism could not be evaluated. M.c. $=$ Myzomela cardinalis

correctly and were polymorphic in 104 individuals. Fragments were amplified by means of the M13-hybrid primer process. In this process, a 16-bp fragment is added to the $5^{\prime}$ end of the forward primer for binding of the dye-labeled M13-hybrid primer (Boutin-Ganach et al. 2001; Schuelke 2000). Primer mixes were prepared as follows: $2 \mu \mathrm{l}$ reverse primer $(100 \mu \mathrm{M}) ; 4 \mu \mathrm{l}$ forward primer $(2.5 \mu \mathrm{M}) ; 4 \mu \mathrm{l}$ 6FAM dye-labeled M13-hybrid primer $(2.5 \mu \mathrm{M}) ; 90 \mu \mathrm{l}$ RNAse/DNAse-free water. Amplification was carried out in $10 \mu \mathrm{l}$ reactions containing $5 \mu \mathrm{l}$ Qiagen Multiplex Mastermix, $0.5 \mu \mathrm{l}$ BSA $(10 \mathrm{mg} / \mathrm{ml}), 1 \mu \mathrm{l}$ primer mix, $2 \mu \mathrm{l}$ RNAse/DNAse-free water, and $1.5 \mu \mathrm{l}$ template DNA (30$100 \mathrm{ng}$ in total). The following cycling conditions were used: an initial step of $95^{\circ} \mathrm{C}$ for $15 \mathrm{~min} ; 25$ cycles of: $30 \mathrm{~s}$ at $94^{\circ} \mathrm{C}, 90 \mathrm{~s}$ at $59^{\circ} \mathrm{C}, 60 \mathrm{~s}$ at $72^{\circ} \mathrm{C} ; 20$ cycles of: $30 \mathrm{~s}$ at $94^{\circ} \mathrm{C}, 90 \mathrm{~s}$ at $53^{\circ} \mathrm{C}, 60 \mathrm{~s}$ at $72^{\circ} \mathrm{C}$; and $30 \mathrm{~min}$ at $60^{\circ} \mathrm{C}$. PCR products were run on an $\mathrm{ABI} 3730$ capillary sequencer, and allele sizes were scored manually using GS 500-LIZ size standard in GeneMapper v3.7 genotyping software (ABI).

Tests for deviations from Hardy-Weinberg equilibrium (HWE) for each locus and each population, and calculations of observed $\left(H_{\mathrm{O}}\right)$ and expected heterozygosity $\left(H_{\mathrm{E}}\right)$ and fixation indices $\left(F_{\text {is }}\right)$ were carried out in GenAlEx v6 (Peakall and Smouse 2006). Tests for linkage disequilibrium (LD) were performed in Genepop 4.0 (Rousset 2008). After Bonferroni correction for multiple comparisons, no consistent departures from HWE were detected across populations $(P>0.05)$. One of the primer combinations (Mr 28) amplified two separate regions, which were highly significantly linked (Mr 28A and $\mathrm{Mr} 28 \mathrm{~B} ; P<0.001)$. Among the remaining loci, LD was only suggested in the population from Saipan for $\mathrm{Mr} 40$ and $\mathrm{Mr} 47$. The number of alleles ranged from 3 to 23 (Table 1). Observed and expected heterozygosities ranged from 0.067 to 0.913 and from 0.065 to 0.918 , respectively. Finally, $F_{\text {is }}$ ranged between -0.143 and 0.634 .

Cross-amplification of primers in other species was evaluated in 18 different Myzomela species and subspecies. DNA was extracted from toe pads collected from museum material using the Qiagen QIAamp DNA Mini Kit according to the manufacturer's protocol for tissue. Most loci amplified well (Table 2), however, because only a single individual per species was available, polymorphism could not be tested. The microsatellites developed here could be useful in population genetic studies of Myzomela honeyeaters, and in the conservation of members of this genus in the tropical Pacific.

Acknowledgments Sample collection was made possible through support from the Netherlands Organisation for Scientific Research (R 87-311), Society for the Advancement of Research in the Tropics (Treub-Mij), Systematics Research Fund, and Alida B. Buitendijk Foundation to HAT. S. Kremer is greatly acknowledged for the donation of feather samples from the Sarigan Myzomela population. E. Hetebrij is thanked for help in sample collection. We thank B. Flint, S. Fretz, J. Hiromasa, S. Kremer, A. Marshall, R. Mauricio, T. Otto, K. Rosa, P. Sweet, E. VanderWerf, L. Williams, and B. Woodworth for collaborations and logistical support in obtaining samples. Toe pad samples were kindly donated by the American Museum of Natural History. 
Open Access This article is distributed under the terms of the Creative Commons Attribution Noncommercial License which permits any noncommercial use, distribution, and reproduction in any medium, provided the original author(s) and source are credited.

\section{References}

Amar A, Amidon F, Arroyo B, Esselstyn JA, Marshall AP (2008) Population trends of the forest bird community on the Pacific island of Rota, Mariana islands. Condor 110:421-427

Boutin-Ganach I, Raposo M, Raymond M, Deschepper CF (2001) M13-tailed primers improved the readability and usability of microsatellite analyses performed with two different allelesizing methods. Biotechnic 31:24-28

Buchanan GM, Butchart SHM, Dutson G, Pigrim JD, Steininger MK, Bishop KD, Mayaux P (2008) Using remote sensing to inform conservation status assessment: estimates of recent deforestation rates on New Britain and the impacts upon endemic birds. Biol Conserv 141:56-66

Driskell AC, Christidis L (2004) Phylogeny and evolution of the Australo-Papuan honeyeater (Passeriformes, Meliphagidae). Mol Phylogenet Evol 31:943-960

Filardi CE, Moyle RG (2005) Single origin of a pan-Pacific bird group and upstream colonization of Australasia. Nature 438: 216-219
Fritts TH, Rodda GH (1998) The role of introduced species in the degradation of island ecosystems: a case history of Guam. Annu Rev Ecol Syst 29:113-140

Jarvi SI, Atkinson CT, Fleischer RC (2001) Immunogenetics and resistance to avian malaria in Hawaiian honeycreepers (Drepanidinae). Stud Avian Biol 22:254-263

Jones KC, Levine KF, Banks JD (2000) DNA-based genetic markers in black-tailed and mule deer for forensic applications. Calif Fish Game 86:115-126

Martins WS, Lucas DCS, de Souza Neves KF, Bertioli DJ (2009) Websat-a web software for microsatellite marker development. Bioinformation 3:282-283

Myers N, Mittermeier RA, Mittermeier CG, da Fonseca GAB, Kent J (2000) Biodiversity hotspots for conservation priorities. Nature 403:853-858

Peakall R, Smouse PE (2006) GENALEX 6: genetic analysis in excel. Population genetic software for teaching and research. Mol Ecol Notes 6:288-295

Pratt HD, Bruner PL, Berrett D (1987) A field guide to the birds of Hawaii and the tropical Pacific. Princeton University Press, Oxford

Rousset F (2008) GENEPOP '007: a complete re-implementation of the GENEPOP software for Windows and Linux. Mol Ecol Res 8:103-106

Schuelke M (2000) An economic method for the fluorescent labeling of PCR fragments. Nature Biotech 18:233-234

Steadman DW (2006) Extinction and biogeography of tropical Pacific birds. The University of Chicago Press, Chicago 